\title{
District Retooling And Upskilling: A Response In Overcoming Challenges Of Teachers In Conducting Research
}

\author{
Lilibeth M. Virtus \\ lilibeth.virtus@deped.gov.ph \\ Department of Education,Banaba West Integrated School, \\ Banaba West ,Batangas City,Batangas,Philippines,4200
}

\begin{abstract}
School heads and teachers as the frontline in the educational system need to develop a deep understanding of teaching phenomena and practices in schools. This understanding can be done through research. Most of the teachers are not motivated to conduct research even if they encountered lots of problems in the new normal. With this, the researchers determine the challenges in researching and provide an immediate response in overcoming challenges. The descriptive-quantitative method was used with 132 teacher participants selected randomly using the Raosoft application from District VIII. While online survey questionnaires and interviews, frequency, percentage, weighted mean, ranking, and t-test were used. The challenges faced by teachers before the conduct of upskilling are lack of knowledge and skills in completing the research; the upskilling is highly effective in terms of content, design, attitude towards the conduct of research, and knowledge and skills development. Meanwhile, the challenges faced after the upskilling are poor time management, and lack of self-confidence; and there is a significant difference before and after upskilling, thus, a proposed innovative Professional Development activity may be utilized to help teachers overcome their challenges.
\end{abstract}

Keywords: District Retooling and Upskilling; Overcoming Challenges in Conducting Research; Conducting Research; A Response In Overcoming Challenges of Teachers

\section{I.Introduction}

The educational spectrum of Philippine education has been undergoing a rapid learning overhaul and radical transformation in this time of the pandemic. This public health crisis and the response of the Department of Education towards continuity of learning have educationally unveiled the creativity, resourcefulness, and resilient capacities of the instructional leaders and teachers.

There are many changes in the curriculum, pedagogy, and learning modalities that have been accelerated by the pandemic. These educational transformations have been a good initiative for a new revival of public education, one that converts the idea of schooling into a learning culture. With these rapid changes arising with the pandemic, it gives the school leaders and teachers time to rethink its strategy to educationally adjust its processes because, at the end of the 
day, the center of any educational process is the human relationship between a student and a teacher.

School heads and teachers as the frontline in the educational system need to develop a deep understanding of teaching phenomena that they encounter in their schools. Through the collection and interpretation of research data, they could advance their practices. Action research is a method that could improve the quality of teaching. According to de Borja (2018), it is valuable to the teaching-learning process for both teachers and students, its positively impacted both students' learning and teaching and leads to the professional growth of their career through ranking and promotions. Furthermore, Hendricks (2017), enables practitioners to be invested in the data collection process, fosters ingenuity, creativity, problem-solving, and academic discovery. Additionally, an instrument in providing opportunities for literacy coaches and classroom teachers to develop and integrate differentiation, explore innovative strategies, and become adept at data analysis Lippert and Bailey (2018). Moreover, Tindowen et, al (2019) increase pedagogical and instructional knowledge and positively impact students' learning.

However, according to Madzniyah, 2006 cited by Othman and Chia (2016), teachers who want to implement action research tend to face challenges in doing so, such as time constraints and heavy workloads. For Qasem and Zayid ( 2019) students and teachers face many challenges and difficulties in composing and writing proposals and research projects. These constraints are selecting the right topic, selecting the right methodology of writing proposals, lack of motivation in writing proposals and projects, lack of good knowledge in specialization, lack of time and stress chiefly out of their preoccupation with other subjects, and less time given from supervisors to students. Likewise, research knowledge and skills, work conditions, time constraints, and logistics are some of the constraints met by teachers Al Ghatami and Al-Husseini (2014). Further, Othman ( 2016) teachers' heavy workloads, time constraints, and a lack of indepth understanding and skills related to this methodology are the challenges. In addition, knowledge of statistics or data analyses, time spent in conducting action research, the number of teaching load, and teacher tasks are the challenges of teachers de Borja (2018).

Thus, to overcome these challenges in researching distance education, teachers can utilize online platforms for technological advancements so they can collaborate and assist one another in navigating the difficulties and complexities Harness and Cusatis, (2016). In addition, coaching strategies may help improve a teacher's problem-solving skills, increase the quality of their reflections, and raise the levels of their work satisfaction thereby developing their professional skills Teemant et al., (2011). Furtheremore, Darling-Hammond et. al (2017) emphasized that teacher's development programs shall ensure that the content focus is curriculum-relevant and builds on what teachers already know and do, or could feasibly do with the resources they have. Tindowen et, al (2019) doing participatory and collaborative action researches, support for more professional development programs, peer mentoring and advising, and other mechanisms that may be formalized and institutionalized. Also, coaching strategies and periodic research conferences and should be made a mandatory component of teachers' official duties and a component of their annual performance evaluations. Selecting a field site and acquiring access, recruiting and building trust, maintaining privacy and confidentiality, and being vulnerable as a researcher must also be considered, Thummapol (2019).

Hence, action research is demanding, complex, and challenging because the teacherresearcher not only assumes responsibilities for doing the research but also for enacting change. Enacting change is not easy - it requires time, patience, and sound planning, communication, and implementation skills. Consequently, in establishing a foundation for conducting action research, the department of education, provides guidance in the conduct of education research and the 
utilization of research results to inform the Department's planning, policy, and program development aligned with its vision, mission, and core values, maximize existing resources and set up platforms for the sharing and use of results ( DO 39, S. 2016). In addition, DepEd continues its initiatives towards strengthening evidence-based policy development and decision-making through the provision of research funds to eligible proponents. (DO 43, S. 2015).

In the 2020 Division Conference on Basic Education Researchers (DCBER), it was very evident that only a few teachers and school heads were able to join in the said conference, despite the motivation and early pronouncement of the conference details from the division personnel. Consequently, the researchers observed that most of the teachers are not motivated to conduct action research even if they encountered lots of problems in the new normal.

Undeniably, the role of the research plays a vital role in understanding own practices, providing solutions to school-related problems, and offering quality education and services to all stakeholders. District VIII of the Division of Batangas City has underscored capacity-building programs on the conduct of action research for school heads and teachers. It feels the educational need to adapt to the new normal of education and capacitate all school heads and teachers in research activities. The conduct of action research has posed challenges and opportunities for teachers as they work to adapt and embrace this rapidly changing environment. With this, the researchers try to find out the reasons for their challenges in researching, the low participation of teacher-researchers in research conferences and provide an immediate response in overcoming challenges.

\section{Research Questions}

This research study aimed to find out the challenges of teachers in conducting, and provide an immediate response in overcoming these challenges.

Specifically, it sought to answer the following questions:

- What are the common challenges faced by the teacher-researchers before the district retooling and upskilling in conducting action research?

- How may the effectiveness of district retooling and upskilling in overcoming challenges of teacher-researchers be described in terms of:

- content;

- design;

- attitude towards the conduct of research; and

- research knowledge and skills development?

- How may teacher-researchers describe their challenges faced after the implementation of district retooling and upskilling?

- Is there a significant difference before and after the conduct of district retooling and upskilling on the common challenges faced by teacher-researchers?

- What innovative District Teachers' Professional Development in conducting research may be proposed to help teachers overcome their challenges?

\section{Hypothesis}

There a significant difference before and after the conduct of district retooling and upskilling on the common challenges faced by teacher-researchers.

\section{Proposed Innovation, Intervention, and Strategy}

District VIII has been developing teachers professional development plan focusing on the 
conduct of action research and taking full advantage of technology for learning will require new professional learning content centered on several key ideas and skills in conducting research, including choosing the right topic and methodologies for research proposal, formulation research plans and conduct of data analysis procedures, interpretation of the data gathered, formulation conclusions and recommendations to complete the research paper.

There are several steps in designing a district professional development plan for school heads and teachers' focusing on how to overcome challenges in the conduct of research. It shall follow the process stipulated in DO memo No.85, S.2019 entitled School-Based In-Service Training (INSET) for Teachers On The K To 12 Learning Delivery Program, DO 12, 2021, entitled amendment to Deped Order No 30, S 2020, Teachers Shall Attend A Professional Development Program Through An In-Service Training INSET Organized By School Or Relevant Units Of Deped. Likewise, Deped Order 35 series 2016, entitled The Learning Action Cell (LAC) as a K To 12 Basic Education Program School-Based Continuing Professional Development Strategy For The Improvement Of Teaching And Learning.

First, Assessment of Needs. Needs are identified concerning the survey conducted by the researchers. These needs could be captured through different forms like self-assessment tools. These are addressed in the statement of problem 1. Second is the Prioritization of Topics or Agenda. This was done by conducting a district meeting led by the Public Schools District Supervisor with the eight (8) school heads.

The third is the Formation of District VIII and Technical Working Group. The technical working group was created by the Public Schools District Supervisor (PSDS). Fourth is the Identification of Appropriate Intervention. The online training could agree on exploring interventions to address the identified need of teachers in overcoming their challenges in the conduct of action research. Fifth, Public Schools District Supervisor with the eight (8) school heads decided on the schedule, length, and frequency of training.

\section{Action Research Methods}

\section{Participants and/or other Sources of Data and Information}

The participants of the study were 132 elementary and secondary school heads and teachers of District VIII in the Schools Division of Batangas City. With the belief that research could improve the quality of education through the activities of teachers who are critically aware of their challenges and performs in the delivery of distance learning and are willing to change their practices. District VIII has expressed its need to retool and upskill the research skills of the school heads and teachers and be able to participate in the Division Conference on Basic Education Researchers (DCBER). District VIII of the Division of Batangas City addresses the need to conduct the training and professional development of school heads and teachers.

The participants range from various teaching designations mostly Teacher I-III and Master Teachers/Officer-In-Charge. Respondents range from 24-56 years old that suggested a lack of competency and experience in conduction research, these group of participants are still open to professional advancement expressing that they need to educationally adjust to the new normal and find solutions to the problems they encountered, be able to participate in research conferences and publish their research works. They have a minimum internet connection and sufficient gadgets to complete the training. The participants are selected through random sampling with a five percent $(5 \%)$ margin of error and $95 \%$ confidence level using the Raosoft application 
from the research procedure conducted. They were subjected to the professional development needs assessment then complete the training and presented their outputs.

To identify the challenges encountered by the teachers in conducting Action Research, an online survey questionnaire was sent. Common challenges were identified. These challenges could be captured through different forms like observations, and surveys. The researchers also conducted focus group discussions to validate the data. After the survey was conducted on the challenges met, the District Retooling and Upskilling was carefully crafted. The researchers conducted a meeting with district school heads for the implementation. After the implementation of the district capacity building was held for five (5) days, an online survey questionnaire one again sent to the respondents to describe the implementation in terms of content, design, attitude towards the conduct of research; and research knowledge and skills development. Likewise, teacher-researchers were also asked through an online survey questionnaire to describe their common challenges faced after the implementation of the district professional development plan for school heads and teachers. After the data has been carefully interpreted, an innovative District Teachers' Professional Development in conducting research may be proposed to help teachers overcome their challenges.

\section{Data Analysis Plan}

The online data results from google forms were statistically analyzed. Due to the Covid19 pandemic, this online survey questionnaire involves preparing and checking the survey data files includes compiling paper surveys in an electronic file, merging data files, checking for data entry errors, and coding the data. For the Statement of Problem 1 which identifies the challenges encountered by the teachers in conducting research, checklists were provided, frequency and percentage were used to analyze the data.

For the descriptive on the effectiveness of District Retooling and Upskilling in overcoming challenges of teacher-researchers, the researchers calculated common summary statistics like means and ranking, scoring of responses such as Highly Effective, Effective, Slightly Effective, and Least Effective with 4,3,2,1 of scales respectively, for each survey item the researchers used specialized statistical software, such as IBM SPSS Statistics, or spreadsheet software, such as Microsoft Excel. In addition, a t-test was used to determine the difference in the challenges faced by teacher-researchers before and after the conduct of district retooling and upskilling.

\section{Results and Findings}

The following presents the results, discussion, and interpretation of the action research.

1. Common challenges faced by the teacher-researchers before the district retooling and upskilling in conducting action research

Table 1 shows that among the challenges met by teacher-researchers lack of knowledge and skills in completing the research ranked first with a frequency of 87 and a percentage of 65.9. This is supported by Al Ghatami and Al-Husseini (2014) that research knowledge and skills are one of the major challenges of teachers. 
Table 1.

Challenges before the district retooling and upskilling

\begin{tabular}{llll}
\hline Challenges & Frequency & Percentage & Rank \\
\hline Lack of motivation & 37 & 28 & 8 \\
Lack of self-confidence & 69 & 52.3 & 4 \\
Poor time management & 76 & 57.6 & 2 \\
Lack of focus or direction & 56 & 42.4 & 7 \\
Stuck in their comfort zone & 24 & 18.2 & 9 \\
Fear of failure/taking risks & 63 & 47.7 & 5 \\
Lack of relevant experiences & 75 & 56.8 & 3 \\
Lack of knowledge and skills in completing the research & 87 & 65.9 & 1 \\
Lack of resources & 62 & 47 & 6 \\
Lack of support & 14 & 10.6 & 10
\end{tabular}

Poor time management, lack of relevant experiences, and lack of self-confidence ranked second, third and fourth with a frequency of 76,75 and 69, and percentage of 57.6,56.8 and 52.3 respectively. Added by Othman ( 2016) that time constraints and a lack of in-depth understanding and skills related to this methodology are also some of the challenges by teachers. Ranked 5 th, $6^{\text {th, }}$ and $7^{\text {th }}$ are fear of failure/taking risks, lack of resources, lack of focus or direction with the percentage of 47.7,47 and 42.4 respectively. These results are similar to the study conducted by $\mathrm{Al}$ Ghatami and Al-Husseini (2014) that failure and logistics are some of the constraints met by teachers in doing scion research. Lack of motivation, stuck in their comfort zone, and lack of support with frequencies of 37,24 and 14 with percentages of 28,18.2 and 10.6 are among the lowest items that gained ranked of $8^{\text {th }}, 9^{\text {th }}$ and $10^{\text {th }}$ respectively.

As a whole, teacher-researchers in District VIII have challenges in conducting research. They have low competency to complete their research and these challenges hinder them to conduct action research, complete their research papers and participate in research conferences. The results of the study are supported by de Borja (2018) that time spent in conducting action research, the number of teaching load, and teacher tasks are teachers' challenges.

2. Effectiveness of district retooling and upskilling in overcoming challenges of teacherresearchers

\subsection{Content}

Table 2.1 reveals the content description of the District Retooling And Upskilling In Overcoming Challenges Of Teacher-Researchers in Conducting Research

Teachers conveyed that the objectives of the workshop are very timely and appropriate to the current educational system and teachers' needs, and the output/ assignment tasks were appropriate to the goals of the course with weighted means of 3.95 and 3.92 respectively verbally interpreted as highly effective.

The topics discussed in the upskilling have increased interest in the field research. The lectures and discussions on different parts of action research complemented each other are both highly effective with a weighted mean of 3.90. Lastly, among the indicators, the districtwide upskilling, the content gave teachers the confidence to be more competent in conducting research registered a weighted mean of 3.86 interpreted as highly effective. 
Table 2.1

Effectiveness of district retooling and upskilling in terms of content

\begin{tabular}{lll}
\hline Indicators & $\begin{array}{l}\text { Weighted } \\
\text { Mean }\end{array}$ & $\begin{array}{l}\text { Verbal } \\
\text { Interpretation }\end{array}$ \\
\hline $\begin{array}{l}\text { The objectives of the retooling and upskilling are very timely } \\
\text { and appropriate to the current educational system and my } \\
\text { needs }\end{array}$ & 3.95 & Highly Effective \\
$\begin{array}{l}\text { The topics discussed in the upskilling have increased my } \\
\text { interest in the field of research }\end{array}$ & 3.90 & Highly Effective \\
$\begin{array}{l}\text { The lectures and discussions on different parts of action } \\
\text { research complemented each other. }\end{array}$ & 3.90 & Highly Effective \\
$\begin{array}{l}\text { The output/ assignment tasks were appropriate to the goals of } \\
\text { the course. }\end{array}$ & 3.92 & Highly Effective \\
$\begin{array}{l}\text { The districtwide upskilling content gave me the confidence to be } \\
\text { more competent in conducting research } \\
\text { Composite Mean }\end{array}$ & 3.86 & Highly Effective \\
\hline
\end{tabular}

The composite mean of 3.91 implies that District Retooling And Upskilling In Overcoming Challenges Of Teacher-Researchers in Conducting Research is highly effective. According to Tindowen et, al (2019) other mechanisms should be adopted by the schools such as the emphasis on doing participatory and collaborative action researches, support for more professional development programs, peer mentoring and advising, and other mechanisms that may be formalized and institutionalized to help teacher-researchers.

For Teemant et al., 2011 coaching strategies may help improve a teacher's problemsolving skills, increase the quality of their reflections, and raise the levels of their work satisfaction thereby developing their professional skills.

\subsection{Design}

The conduct of district retooling and upskilling in overcoming challenges of teacherresearchers is highly effective in balancing and achieving everyday tasks with a weighted mean of 3.94. There are the quality of the speakers, presentation, and examples presented, there is the consistency of the content with the objectives teachers rated the course design indicators as 3.93 interpreted as highly effective. The training has a considerable amount of material resources and increased interest in this field of study covered which the teachers rated of 3.92 interpreted as highly effective. 
Table 2.2

Effectiveness of district retooling and upskilling in terms of design

\begin{tabular}{lll}
\hline Indicators & $\begin{array}{l}\text { Weighted } \\
\text { Mean }\end{array}$ & Verbal Interpretation \\
\hline $\begin{array}{l}\text { There are the quality of the speakers, presentation, and } \\
\text { examples presented }\end{array}$ & 3.93 & Highly Effective \\
$\begin{array}{l}\text { There is the consistency of the content with the } \\
\text { objectives }\end{array}$ & 3.93 & Highly Effective \\
$\begin{array}{l}\text { Balance is achieved in everyday task } \\
\begin{array}{l}\text { The topics discussed in the training has increased my } \\
\text { interest in conducting research }\end{array}\end{array}$ & 3.90 & Highly Effective \\
$\begin{array}{l}\text { There is a considerable amount of technological } \\
\text { resources used }\end{array}$ & 3.90 & Highly Effective \\
Composite Mean & 3.93 & Highly Effective \\
\hline
\end{tabular}

The composite of 3.93 implies that the training design conducted is well planned, crafted, and highly effective. The results are supported by Darling-Hammond et. al (2017) that teacher's development program shall focus on content design and ensure that the design focus is curriculum-relevant.

\subsection{Attitude towards the conduct of research}

Table 2.3 reveals that teachers have an overall positive attitude towards district upskilling considering learning valuable during the pandemic with a weighted mean of 3.82 interpreted as highly effective.

Table 2.3

Effectiveness of district retooling and upskilling in terms attitude

\begin{tabular}{lll}
\hline Indicators & $\begin{array}{l}\text { Weighted } \\
\text { Mean }\end{array}$ & $\begin{array}{l}\text { Verbal } \\
\text { Interpretation }\end{array}$ \\
\hline $\begin{array}{l}\text { I consider my learning in conducting research valuable } \\
\text { especially in the new normal }\end{array}$ & 3.87 & Highly Effective \\
$\begin{array}{l}\text { I am excited when I learn new knowledge and skills in } \\
\text { accomplishing my research }\end{array}$ & 3.85 & Highly Effective \\
$\begin{array}{l}\text { There is enjoyment as I learn many things in conducting } \\
\text { research }\end{array}$ & 3.86 & Highly Effective \\
$\begin{array}{l}\text { I have been challenged and guided to learn more than I } \\
\text { expected }\end{array}$ & 3.84 & Highly Effective \\
$\begin{array}{l}\text { I was stressed in finishing the outputs but delighted in the } \\
\text { information I gained in the training } \\
\text { Composite Mean }\end{array}$ & 3.68 & Highly Effective \\
\hline
\end{tabular}


This means that teachers are willing to learn and finish their researches. They believed that it helps them improve their professional skills and capabilities, understand the educational system Al Ghatami (2014).

The district upskilling is highly effective. Data revealed that conducting research is valuable especially in the new normal gained a weighted mean of 3.87. In addition, teachers enjoy as they learn many things in conducting research, learning new knowledge and skills in accomplishing research, been challenged, and guided to learn more than they expected and was stressed in finishing the outputs but delighted in the information gained in the training with a weighted means of $3.86,3.85,3.84$, and 3.68 respectively interpreted as highly effective.

The teachers' positive attitude towards change in educational research is needed to be adapted to an innovative training where research culture is predominant

\subsection{Research knowledge and skills development}

Table 2.4 shows that District retooling and upskilling in overcoming challenges of teachers. With a composite mean of 3.82, data revealed that upskilling is highly effective. Teachers believed that it helped them to develop their research knowledge and skills. According to de Borja (2018), action research is valuable to the teaching-learning process for both teachers and students, its positively impacted both students' learning and teaching and leads to the professional growth of their career through ranking and promotions.

Table 2. 4

Effectiveness In Terms Research Knowledge And Skills Development

\begin{tabular}{lll}
\hline Indicators & $\begin{array}{l}\text { Weighted } \\
\text { Mean }\end{array}$ & $\begin{array}{l}\text { Verbal } \\
\text { Interpretation }\end{array}$ \\
\hline $\begin{array}{l}\text { The district upskilling improved my skills in choosing a } \\
\text { topic and finding related literature/studies for my research }\end{array}$ & 3.83 & Highly Effective \\
$\begin{array}{l}\text { I became more familiar with the different parts of the } \\
\text { research }\end{array}$ & 3.81 & Highly Effective \\
$\begin{array}{l}\text { The training increased my knowledge and skill in preparation } \\
\text { of research proposal }\end{array}$ & 3.85 & Highly Effective \\
$\begin{array}{l}\text { I learned simple statistical tools, data gathering, presentation } \\
\text { and discussion of results, and formulating conclusions and } \\
\text { recommendations }\end{array}$ & 3.80 & Highly Effective \\
$\begin{array}{l}\text { The training helped me understand how to finish my action } \\
\text { research }\end{array}$ & 3.83 & Highly Effective \\
Composite Mean & 3.82 & Highly Effective \\
\hline
\end{tabular}

With a weighted mean of 3.85 , interpreted as highly effective, teachers have increased their knowledge and skill in preparation of research proposals, but according to $\mathrm{Al} \mathrm{Ghatami}$ and Al-Husseini (2014) that research knowledge and skills are one of the major challenges of teachers in conducting research.

Teachers improved skills in choosing a topic and finding related literature/studies for 
research, helped them to understand how to finish action research, became more familiar with the different parts of the research, learned simple statistical tools, data gathering, pres entation, and discussion of results, and formulating conclusions and recommendations gained a weighted means of 3.83,3.81and 3.82 correspondingly. This is contrary to Qasem and Zayid ( 2019) that teachers face many challenges and difficulties in composing and writing proposals and research projects. These difficulties include choosing the right topic, selecting the right methodology of writing proposals, and a lack of good knowledge in the specialization.

3. Descriptions of the challenges faced after the implementation of district retooling and upskilling

Table 3 reveals the challenges faced by teachers after the conduct of District Retooling and Upskilling. Ranked first shows that teachers have poor time management with a frequency of 66 and a percentage of 50. Lack of self-confidence, fear of failure/taking risks, and lack of relevant experiences are ranked second, third, and fourth among the 10 items. These items obtained frequencies of 56,50 and 39 and percentages of 42.4,37.9 and 29.5 respectively. This result is similar to the study of Othman ( 2016) that teachers' heavy workloads, time constraints, and a lack of in-depth understanding and skills related to this methodology are the challenges.

Table 3

Challenges After The District Retooling And Upskilling

\begin{tabular}{lccc}
\hline \multicolumn{1}{c}{ Challenges } & Frequency & Percentage & Rank \\
\hline 1. Lack of motivation & 18 & 13.6 & 8 \\
2. Lack of self-confidence & 56 & 42.4 & 2 \\
3. Poor time management & 66 & 50 & 1 \\
4. Lack of focus or direction & 35 & 26.5 & 6 \\
5. Stuck in their comfort zone & 15 & 11.4 & 9 \\
6. Fear of failure/taking risks & 50 & 37.9 & 3 \\
7. Lack of relevant experiences & 39 & 29.5 & 4 \\
8. Lack of knowledge and skills in completing the & & & \\
research & 30 & 22.7 & 7 \\
9. Lack of resources & 37 & 28 & 5 \\
10. Lack of support & 5 & 3.8 & 10 \\
\hline
\end{tabular}

Moreso, for Hendricks (2017) research studies enables practitioners to be invested in the data collection process. Educators become revitalized while conducting studies where such a goal fosters ingenuity, creativity, problem-solving and academic discovery.

With frequencies of 18,15 and 5 and percentages of 13.6,11.4, and 3.8 correspondingly, teachers' lack of motivation, being stuck in their comfort zone, and lack of support are among the three lowest in ranks. These are different from the results of the study by Thummapol (2019), selecting a field site and acquiring access, recruiting and building trust, maintaining privacy and confidentiality, and being vulnerable as a researcher is among the challenges of researchers.

As a whole, after the conduct of district retooling and upskilling, knowledge and skills improved but time management is the constraint of teachers.

4. Difference before and after the conduct of district retooling and upskilling on the common challenges faced by teacher-researchers 
Table 4

Difference before and after the conduct of district retooling and upskilling

\begin{tabular}{lccllll}
\hline Variables & Mean & $\begin{array}{l}\text { Critical } \\
\text { values }\end{array}$ & $\begin{array}{l}\text { Computed } \\
\text { t-value }\end{array}$ & $\begin{array}{l}\text { P- } \\
\text { value }\end{array}$ & Decision & Interpretation \\
\hline $\begin{array}{l}\text { Before } \\
\text { After }\end{array}$ & 56.10 & \pm 2.262 & -4.412 & 0.002 & Reject Ho & Significant \\
\hline
\end{tabular}

$\mathrm{P}$-value is significant at $5 \%$ level (2-tailed)

It can be observed that P-value of 0.002 less than 5\% level of significance, suggested that the null hypothesis must be rejected since it is significant. It can be also gleaned that the computed $\mathrm{t}$-value of -4.412 is less than the critical value of 2.262. It implies that after the conduct of district retooling and upskilling to overcome challenges in conducting research, teachers learned on how to conduct researches, and overcome their challenges. In addition, the results confirmed that the upskilling is effective in terms of content, design, attitude towards the conduct of research, and research knowledge and skills development.

Meanwhile, according to Harness and Cusatis, ( 2016) to overcome challenges in conducting research in distance education, teachers can utilize online platforms for technological advancements so they can collaborate and assist one another in navigating the difficulties and complexities. In addition,for Teemant et al., (2011) coaching strategies may help improve a teacher's problem-solving skills, increase the quality of their reflections, and raise the levels of their work satisfaction thereby developing their professional skills .

5. Other innovative district teachers' professional development activities may be proposed to help teachers overcome their challenges

Here are the proposed Innovative District Teacher's Professional Development activities to further overcome challenges in conducting action research.

Webinars Focusing on Discussion of Results and Formulation of Conclusions and Recommendations. An online event that is hosted by the researchers and invited experts t through the use of online platforms on the data collection, resentation, analysis, discussion and interpretation, formulation of conclusions and recommendations

Online School's Learning Action Cell. Group of teachers engage in collaborative learning sessions to solve shared challenges encountered in the school facilitated by the school head or a designated LAC Leader or experts, the topics that will be discussed is all about the methodology of research.

Virtual In-Service Trainings (VINSET).The process by which teachers engage in further training on conducting research to refresh or upgrade their professional knowledge, skills, and practices.By conducting school-national based training about research teachers will be equipped with enough knowledge and skills that can be applied in the new process of making research in normal education.

Virtual Coaching. It is an in-person coaching conversation that is conducted over a web-based video conferencing service (also known as video chat or video call through Google meet). One or more people will enjoy a development experience that is facilitated by a qualified research coach. 


\section{Conclusions} formulated:

Based on the salient point emphasized in the study, the following conclusions were

The common challenges faced by teacher-researchers before the conduct of district retooling and upskilling are lack of knowledge and skills in completing the research, poor time management, and lack of relevant experiences. The District retooling and upskilling in overcoming challenges of teacher-researchers in terms of content, design, attitude towards the conduct of research and research knowledge and skills development respondents is highly effective.The common challenges faced by the teacher-researchers after the district retooling and upskilling in conducting research are poor time management, lack of self-confidence teachers and the desire to complete research.There is a significant difference before and after the conduct of district retooling and upskilling on the common challenges faced by teacher-researchers. Thus, the null hypothesis is rejected. The innovative District Teachers' Professional Development Activities that may be proposed to help teachers further overcome their challenges are Webinars focusing on discussion of results and formulation of conclusions and recommendations, online school's learning action cell, virtual in-service training (VINSET), and Virtual Coaching.

\section{Recommendations}

Based on the findings and conclusions presented, the following recommendations are suggested.The proposed innovative District Teachers' Professional Development Activities may be utilized to help teachers overcome their challenges in conducting research. The number of teaching load and teachers tasks may be lessened by the school head to give extra time for teachers in conducting research. Teachers do not have time for doing research therefore periodic retooling and upskilling and research conferences should be made a mandatory component of teachers' official duties and a component of their annual performance evaluations. Webinars in enhancing attitudes and commitment to service may be conducted to enhance teachers' motivation, confidence toward work and research.

\section{Acknowledgements}

Without the support of the Public Schools District Supervisor, Dr. Rosalinda M. Comia,District VIII school heads and teachers, this study would not have been completed. It is to them that the researchers owe the deepest gratitude.

\section{References}

Al Ghatami, Sulaiman And Al-Husseini, Suleiman. Teacher Research: Practice, Challenges And Prospect For Improvement: An Empirical Study From Oman. Sultan Qaboos University. September 2014.

Https://Www.Researchgate.Net/Publication/328901011_Teacher_Research_Practice_Challen ges_And_Prospect_For_Improvement_An_Empirical_Study_From_Oman

de Borja, Joanna Marie. Teacher action research: Its difficulties and implications. Humanities \& Social Sciences Reviews 6(1):29-35 DOI:10.18510/hssr.2018.616. May 2018. Laguna State 
Polytechnic University-San Pablo City Campus

https://www.researchgate.net/publication/324980081_Teacher_action_research_Its_difficulti es_and_implications

Hong, Carrie Eunyoung, Paterson, William. Action Research in Teacher Education: Classroom Inquiry, Reflection, and Data-Driven Decision Making Journal of Inquiry \& Action in Education, 4(2), 2011 University Salika A. Lawrence William Paterson University

Joosten, T., Harness, L., and Cusatis, R. (May, 2016).

National Research Center For Distance Education And Technological Advancements deta. https://uwm.edu/deta/top-5challenges-in-conducting-deta-research/

Lippert, Kathi ED,D. and Bailey, Cassie MA. The Instructional Coach Academy

Originally published for Olivet Nazarene University. November, 2018. Copyright 20182022

Othman, Norasmah and Chia, S.Y.The Challenges Of Action Research Implementation In Malaysian Schools. Universiti Kebangsaan Malaysia

Qasem, Fawaz And Zayid, Elrasheed Ismail M. The Challenges And Problems Faced By Students In The Early Stage Of Writing Research Projects In L2, University Of Bisha, Saudi Arabia, Doi:10.5281/Zenodo.2557036. January 2019. European Journal Of Special Education Research Volume 4, Issue 2019

https://docs.google.com/document/d/1YLfdS3DhYYlx_y6N8792bd8xPgbNNMstHBcPTXnSo0/edit\#

Tindowen, Darin Jan; Macanang, Domer \& Guzman, Joy. Teachers' Conception and Difficulties in Doing Action Research, Universal Journal of Educational Research 7(8):1787-1794 Center for Social Innovation, Local Knowledge and Educational Research, University of Saint Louis, Tuguegarao City, Philippines

DOI:10.13189/ujer.2019.070817. Saint Louis University, Baguio City, August 2019,https://www.researchgate.net/publication/334963031Teachers' Conception and Difficulties in_Doing_Action_Research

Thummapo, Onouma 1(D), Park Tanya , Jackson Margot , Barton Sylvia,Methodological Challenges Faced in Doing Research With Vulnerable Women: Reflections From Fieldwork Experiences. First Published May 6, 2019

Legal Documents

DO 39, S. 2016 - Adoption Of The Basic Education Research Agenda

DO 43, S. 2015 - Revised Guidelines For The Basic Education Research Fund (BERF) 